\title{
I SURVIVED CANCER: PHENOMENOLOGICAL ANALYSIS OF THE SURVIVORS' LANGUAGE
}

\author{
Catarina Aparecida Sales ${ }^{1}$, Carla Simone Leite de Almeida ${ }^{2}$, Julia Wakiuchi ${ }^{3}$, Kelly Cristine Piolli ${ }^{4}$, Kesley de \\ Oliveira Reticena ${ }^{5}$
}

\footnotetext{
${ }^{1}$ Ph.D. in Nursing. Professor of the Universidade Estadual de Maringá (UEM). Maringá, Paraná, Brazil. Email: casales@uem.br

${ }^{2}$ Doctoral student on the Postgraduate Program in Nursing at UEM. Professor of the Santa Catarina Federal Institute. Joinville, Santa Catarina, Brazil. E-mail: calmone@bol.com.br

${ }^{3}$ Doctoral student on the Postgraduate Program in Nursing at UEM. Fellow of the CAPES, Maringá, Paraná, Brazil. E-mail: julia.wakiuchi@gmail.com

${ }^{4}$ Master's student on the Postgraduate Program in Nursing at UEM. Professor of the Paraná Adventist College. Ivatuba, Paraná, Brazil. E-mail: kellyiap.enf@gmail.com

${ }^{5}$ Master's student on the Postgraduate Program in Nursing at UEM. Fellow of CAPES. Maringá, Paraná, Brazil. E-mail: kesleyreticena@hotmail.com
}

\begin{abstract}
The study attempted to understand the feelings of people who have survived cancer, through qualitative research with Heidegger's phenomenological approach. The study subjects were five cancer survivors, followed up during 2004 and 2005 through a university extension project in the northwestern region of the state of Paraná. Phenomenological interviews were held to capture the survivors' feelings, at their homes, during January and February 2013. "How is it for you to have survived cancer?" was the orienting question. Four ontological issues emerged from the analysis of their discourses: (re-) remembering the vigor of having been; (re-) encountering spirituality; fear of the disease's recurrence; forgetting the temporality of living with cancer. We conclude that, in their being-healed, patients live with anxiety, that throws them into a distressing state for fear of recurrence, as well as enabling them to find a new meaning to life.
\end{abstract}

DESCRIPTORS: Neoplasms. Survivorship. Nursing care.

\section{SOBREVIVI AO CÂNCER: ANÁLISE FENOMENOLÓGICA DA LINGUAGEM DOS SOBREVIVENTES}

RESUMO: Buscou-se compreender os sentimentos de pessoas que sobreviveram ao câncer, por meio da pesquisa qualitativa, com a abordagem fenomenológica heideggeriana. Foram sujeitos cinco sobreviventes de câncer, acompanhados entre os anos de 2004 e 2005 por um projeto de extensão universitária no Noroeste do Paraná. Para captar os sentimentos dos sobreviventes, foi utilizada a entrevista fenomenológica. As pessoas foram entrevistadas, no próprio domicílio, entre os meses de janeiro a fevereiro de 2013, com a seguinte questão norteadora: “Como está sendo para você ter sobrevivido ao câncer?" Da análise dos discursos, emergiram quatro temáticas ontológicas: (Re) Lembrando o vigor de ter sido; (Re) Encontrando-se com a espiritualidade; Temendo a recidiva da doença; Esquecendo-se da temporalidade de existir com câncer. Concluímos que, em seu sendo-curada, as pacientes convivem com a angústia, que as lança a um estado aflitivo pelo temor da recidiva, como também as possibilita encontrar um novo sentido à vida.

DESCRITORES: Neoplasias. Sobrevida. Cuidados de enfermagem.

\section{SOBREVIVI AL CÁNCER: ANÁLISIS FENOMENOLÓGICA DEL LINGUAJE DE LOS SOBREVIVINTES}

RESUMEN: Buscamos comprender los sentimientos de personas que sobrevivieron al cáncer, por medio de la investigación cualitativa e abordaje fenomenológica heideggeriana. Fueron sujetos cinco sobrevivientes de cáncer, acompañados entre los años de 2004 y 2005 por un proyecto de extensión en el Noroeste de Paraná. Para captar los sentimientos de los sobrevivientes fue usada la entrevista fenomenológica. Las personas fueron entrevistadas, en el propio domicilio, entre los meses de enero a febrero de 2013, con la siguiente cuestión: “¿Cómo es para usted haber sobrevivido al cáncer?” Emergieron cuatro temáticas ontológicas: (Re) Acordándose el vigor de haber sido; (Re) Encontrándose con la espiritualidad; Temiendo la recidiva de la enfermedad; Olvidándose de la temporalidad de existir con cáncer. Llegamos a la conclusión que, en su ser-sanado, los pacientes viven con la angustia, que lanza en un estado penoso, por temor a la recurrencia, así como permite encontrar un nuevo sentido a la vida.

DESCRIPTORES: Neoplasias. Sobrevida. Atención de enfermería. 


\section{INTRODUCTION}

Cancer has been shown to be one of the main causes of mortality in the world, deserving special attention on the part of health professionals so as to mitigate the suffering, as the mortality rate is high, although for many cases, cures occur. When somebody receives a diagnosis of cancer, therefore, which brings the stigma of an incurable illness, there appears in their life the inevitable possibility of death. ${ }^{1}$

As a result, being with cancer goes beyond physical pain and emotional discomfort, which cause the person to be immersed in an existential nothingness, due to interfering in the objectives of life of the patient, her family, her work and income. Her mobility, body image and life-style can be drastically changed, temporarily or permanently, producing repercussions which affect all those involved. ${ }^{2}$ Within this temporality, the person moves between the constant shadow of death and the hope of surviving the illness.

Regarding survival following cancer, the literature indicates that, in the United States of America, patient survival has tripled in the last 30 years, indicating nearly $10,000,000$ people, due to the advance of discoveries in early diagnosis and of new technologies for treatment. In that country, the patient with a diagnosis of cancer has a $64 \%$ chance of survival over five years, compared with a rate of $50 \%$ three decades ago. ${ }^{3}$ In Brazil, according to the National Cancer Institute (Inca), ${ }^{4}$ relative survival expected for all the types of cancer is approximately $50 \%$ at five years. However, there is still a need for studies evaluating the survival of patients with cancer, in a more routine and continuous way, over long periods of time, as already takes place in some countries. ${ }^{4}$

The temporality of living with cancer and its treatment pass negative feelings on to the patient, often making her saddened and thinking that things are becoming increasingly difficult. Such thinking supports the feelings of inability and impotence when faced with the situations. ${ }^{5}$

The project "Palliative care for cancer patients and their families" began in 2004, so as to provide a meeting place with patients who experience cancer in their daily life. This has, as a fundamental objective, the accompanying of cancer patients and their families in their homes, the offering of holistic support to these patients and their needs, through the use of the principles of palliative care. ${ }^{6}$
In the above-mentioned project, we noticed that, in experiencing the confirmation of the diagnosis of cancer, the person feels the desire to be cared for, loved, understood, and, principally, to share her concerns and fears. ${ }^{7}$ In this trajectory, we shared the patient's fear before the uncomfortable possibility of death, which persists in silencing life, which still lived in her body, annihilating not only the private things of the ill person, but also her dreams of living a pleasurable future.

Equally, in having her daily life invaded by a neoplastic illness, the individual has the possibility of finding a new meaning to life and transcending its vicissitudes, ${ }^{8}$ such that the same anxiety which accompanied the patient and her family along difficult paths in search of the cure causes the same to leave the state of collapse in which they find themselves and glimpse the resplendence of a new horizon. Thus, from the rare moments resulting from the temporality experienced by those whose cancer was stabilized, arises the disquiet: what is the meaning of life for the people who survive cancer?

This existential condition causes a different understanding to emerge for care in oncology, transposing a "doing" which goes beyond care for signs and symptoms of the disease, and requires of the health professional a concern with emotional, social and psychological aspects so as to maintain the person's quality of life. In the light of the above, this study's purpose was to understand the feelings of people who survived cancer.

\section{METHOD}

For this study, we selected qualitative research, with the Heideggerian phenomenological existential approach. Phenomenology places, as the starting point for its reflection, the person who one can know immediately, that is, Man himself, placing him within an ontological dimension. It allows the understanding of the being, as it is that which is hidden in that which is manifested through the language. ${ }^{9}$

Phenomenological verification does not start from a problem but from a questioning. When the researcher questions, she has a trajectory and walks towards the phenomenon, in that which manifests itself, through the language of the person who experiences the situation. Thus, to know something which leads us to the understanding the concepts of the people who survived cancer, we must question them in their mundanity of the world, that is, in their own human world where 
they experience the phenomenon to be revealed, ${ }^{9}$ which constitutes our region of inquiry.

The research subjects in question were from the extension project titled "Palliative care for cancer patients and their families", elaborated and implanted in 2004 in the Universidade Federal de Maringá, which has monitored patients with cancer receiving palliative care since 2004 to the present day. Between the years 2004 and 2005, the project accompanied 15 people receiving cancer treatment, who continued to be monitored until the situation stabilized, that is, until they no longer presented symptoms of the disease, or until they died. The interest in investigating these peoples' survival arose in 2012, through the request of a survivor who wished to present her experiences.

In seeking this study's subjects, in previously-arranged visits, we met eight ex-participants of the project who had survived cancer. Emphasis is placed on the significant number of survivors, considering that the project in question monitored patients with few perspectives of a cure. We reiterate that, in this project, we considered that the palliative care was to be introduced to the cancer patient since their diagnosis, and not only for those with no perspective of a cure. ${ }^{10}$ As inclusion criteria for the interviewees, besides participation in the above-mentioned project, the patient could not have presented recurrence of the cancer in the last seven years; must live in the city of Maringá in the state of Paraná-PR; and be aged over 18 years old. Those who had other comorbidities prohibiting their participation were excluded, as were those who died before the data collection.

Among the eight patients found, three were excluded, as the disease had recurred in one and she died before the data collection period; a second person moved city, causing us to lose contact; and the third lacked psychological conditions to answer the questions due to the onset of Alzheimer's disease. As a result, interviews were held in the period of January to February 2013 with the five people who had survived cancer.

As this is a study involving human beings, the ethical aspects regulated by Resolution N. $466 / 2012$ of the National Health Council were observed. The proposal of intention to undertake the study was considered and approved by the Universidade Federal de Maringá's Standing Committee For Ethics in Research With Human Beings (Opinion N. 233.634). We also make clear that the participants were assured free consent and the liberty to withdraw from the study at any moment if they so wished; confidentiality, regarding the information provided; and anonymity whenever the results were published.

Thus, following the first contact with the former participants in the project, we returned to their homes to explain the research and request their participation. Following the survivor's authorization, we began the interviews in each person's home, with the aim of capturing their feelings and also their body language. A digital recorder was used and the recordings produced, based on the subjects' discourses, will be kept for a period of five years and then discarded.

In our opinion, the description of experiences must involve thoughts, feelings and actions relating to the reality experienced. In this regard we asked the informants the following guiding question: "How is it for you to have survived cancer?" To maintain their anonymity, they were referred to as S1, S2, S3, S4 and S5.

To capture the fullness expressed by the subjects in their languages, we selected the individual analysis of each discourse. Thus, a priori, we undertook close readings of each account, separating the excerpts or units of meaning which, for us, were shown to be fundamental structures of the existence of the participants interviewed. ${ }^{11} \mathrm{~A}$ posteriori, we moved on to analyze each account's units of meaning, undertaking phenomenological selection of the language of each subject, ${ }^{11}$ which produced ontological themes, analyzed in the light of some Heideggerian ideas, and in the light of the ideas of specialists on the issue and researchers who discuss palliative care.

\section{RESULTS AND DISCUSSION}

Based on the analysis of the participants' language, four ontological themes emerged: (Re-) Remembering the vigor of having been; (Re-) Encountering spirituality; Fear of the disease's recurrence; and, Forgetting the temporality of existing with cancer.

\section{(Re-) Remembering the vigor of having been}

In his work Being and Time, Heidegger presents the interpretation of the authentically existing man, that is, the being-there in her totality. For the thinker, in anticipation of death, being-there exists authentically. The natural ontological foundations of the existentiality of the being-there are the temporality and the historicity. ${ }^{9}$ 
In the forward-looking decision, that is, in the originality and authentic form of caring, the man reveals all his potentiality-for-being, it being the case that this potentiality-for-being is manifested in a temporal constitution. It is a primitive temporality which is temporalized in accordance with three ek-stases. What is to come (future), the vigor of having been (past) and the actuality (present).

In this temporality, learning to be an entity for death, the being-there perceives herself to be thrown into the world and experiencing the facticity of her existence. The temporal movement through which she makes the return to her thrownness constitutes the past. In Heideggerian thinking, it is through projecting himself towards the past that the man can sight and take responsibility for his being-in-the-world. ${ }^{9}$

In this temporal projection, the being-there also becomes historical, but the historicity of this being does not reside in the simple fact of the Being-in-the-world being the object or subject of the history, but of having a destiny. In this case, history does not mean only what has passed, but also its origin and meaning for the person. ${ }^{9}$ "The human being can return to the past, because life can be summarized, and crystalizes in significant forms, of meaning and value."12:137

Based on the above, we visualized, in the subjects' languages, that being cured from cancer in this ik-stante does not erase the memories of their vigor of having been. "The past always has meaning only in the extent to which it is seen from the present." 12:136 And, in this actuality, the patients demonstrate anxiety and suffering experienced in the times when they were subjected to the treatment. The time of chemotherapy stands out from the others as having had the most impact, through its effects and characteristics which invade the patients' lives.

[...] So I began to do it, I did six months, but that was all week, Monday, Tuesday, Wednesday, Thursday and Friday, I did it every day, and that chemotherapy was very strong. I lost my hair, my skin all peeled, it was like being on fire inside, you know, and nothing stayed in my stomach, nothing, nothing, nothing, dysentery which left nothing of food inside me. So, I ate and I stayed lying quietly on the bed, if I moved, pronto, I had to go to the bathroom, so then I would go to the kitchen to eat again, because the hunger was like not being able to breathe. I was ill for six months, six months... I am 77 years old, now, today I am well, except now we cry (S1). [...] I said that I would confront it, but I didn't know that I would suffer so much with the treatment. I did the treatment, but I suffered, because it makes you very sick, gives you a headache, it was breast cancer, how I suffered... my God! After so much praying, I was praying, and I got better, but I was very low indeed, I thought I was going to die, I had no confidence in anything. Six months of chemotherapy, they were really hard (S2). The surgery went well. The difficult part came later, which was doing the chemotherapy and radiotherapy. The chemotherapy was the most difficult, as you had to be well fed, the platelets had to be normalized, if not, you couldn't do the sessions, and I would have to strengthen myself and return another day. I had a lot of sickness and I didn't want to eat (S3).

In the narratives, we surmise that the chemotherapy treatment was revealed to these beings permeated with suffering, not only in the physical sphere, but covering the entire human dimension of the same. This feeling caused us to understand that, in discovering-oneself-in-the-world with cancer, at many times, the patient becomes incapable of understanding herself, living submersed in her own solitude, in which her dreams remain entangled in existence, in a natural relationship in which the I-patient is entire in her world and the world is entire in her illness.

In consonance with these findings, the literature reveals that, even after learning that her disease is stabilized, the patient who has experienced cancer remains with strong feelings in relation to the illness, which include the fear of dependence on the other and the fear of finitude. ${ }^{13}$ This is because the profound marks left by living with cancer remain coupled with the individual's life, and last while her memories are equally intense and connected to her feelings.

\section{(Re-) Encountering spirituality}

When the possibility of imminent death comes to the being-in-the-world, principally through a disease such as cancer, initially the same is cast down, her life loses its meaning, and she feels abandoned by God. However, this Being being a temporal being, this temporality of existing-in-the-world with cancer causes her to understand herself always in this or that manner, considering that the ex-sisting also brings the positive possibility of becoming a whole in something.

In the ambit of the Heideggerian analysis, it is in projecting oneself towards the most appropriate possibility that the man can sight and take responsibility for his being-in-the-world, 
realizing himself and improving in the real time of his life, basing himself in his temporality. ${ }^{9}$ This temporality brings to the Being-there the capacity to precede herself and re-encounter with God, and her spirituality, during the treatment and afterwards, feeling her life to be restored and, mainly, her own power, that is, as a being of care.

For these individuals, spirituality is considered a vital element in the search for purposes and meanings to life, reaching the most intimate part of existence. ${ }^{14}$ It is a search for answers which transcends the moment being lived, in assisting adaptation of the organization for the sake of higher purposes, re-thinking life's concepts and priorities, that is, the search for meaning. ${ }^{15}$

In evaluating the relationship between spirituality and cancer, studies mentioned that cancer patients pass through delicate points in the course of the discovery, treatment and cure; as, initially, they pass through a state of shock; after, they note that what is happening is real, and that they do not know what to think; and, later, they begin to plan the future with hope, ${ }^{16}$ clinging to their faith.

In this understanding, we understand, based on the subjects' language, that the patients, in accepting that they are a cancer survivor, seek new horizons for rebuilding their lives; and, principally, reciprocating the grace received, caring for those next to them and being beside other patients who experience the same existential situation. In these cases, the disease may be understood as liberating, as it allows the person to find the true meaning of life, a discovery of oneself. ${ }^{3}$

I thank God all the time, all the time. We become emotional [...] I am grateful to my doctor all the time, and I thank God for having given me back my health. I feel well now, it is because of this that I have to care for the sick. God gave me the health that I had, better than before, and I help all the patients who come here. Those who need me, I go to the hospital with them, and at home, I care, helping to bath them, because it seems that it is an obligation that I have to help those in need, as God gave me back my health (S1). It has been 11 years, I survived, but I fought a lot for this survival, I believed in God and in the doctors who treated me every time I did the tests, they comforted me, saying 'congratulations, you're managing, and you're going to pull through'. Today, I just do annual checkups, I am well and I don't think about this anymore, I just thank God for this survival (S3).

In the narratives we also learn that to have survived cancer allowed the interviewees a new way of seeing the world and the people around them, a fact corroborated by studies which evidenced the reorganization of life strategies and a new signification for the routine facts by patients who experienced cancer in their lives. ${ }^{17-18}$ In this perspective, spirituality is an important dimension of man, which, added to the biological, intellectual, emotional and social dimensions, constitutes that which differentiates man in his uniqueness and personality. ${ }^{19}$

Spirituality is an expression of identity and the purpose of life of each one, in the light of their own history, experiences and aspirations. The relief of suffering occurs to the extent that religious faith allows changes in the perspective through which the patient and the community perceive the serious illness. ${ }^{16}$

\section{Fearing the disease's recurrence}

In the Heideggerian analysis, the disposition or affective tonality is raised regarding the past, when the man eventually retracts to the world of forgetting, to his having-been-thrown. The philosopher states that the disposition is characterized in mood or affectivity, representing the ways that the man expresses himself in the world in his being-thrown. In this temporal analysis of the mood, the author patents the fear and the anxiety. ${ }^{9}$

The fear is characterized as an inappropriate disposition, as the fear finds its opportunity in the entities which support it, detecting a "malum futurum". The existential and temporal meaning of the fear constitute a forgetting of oneself. The fear affords the withdrawal of the Being-there from his more appropriate potentiality-for-being and, in this forgetting, he no longer recognizes himself in his surrounding world and does not visualize the various possibilities around him, as, in the fear, the man becomes agitated in relation to the world, becoming afflicted and troubled. ${ }^{9}$

During the reading of the accounts, we visualize the possibility of the recurrence of the cancer as the intramundane entity which was already present and which can come again to the human beings in this study, provoking in them the feeling of fear in the light of the probability of having once again to experience the presence of cancer in their bodies. This possibility brings into their lives a mixture of fear and uncertainty, which surround the fear of the recurrence and re-approximation with death at every moment in which it is remembered. ${ }^{20}$ 
[...] I say this, that I am well, but all of a sudden the others begin talking, someone has died from this or that, and I begin to feel lower. A friend of my daughter died recently, my colleague, her mother wants to say, she died... She had cancer too, five years ago, and she despaired, I started crying. And recently, many memories have come back and I say 'I don't want to think about this', but soon afterwards, the news comes that someone died of this, and we get all of that in our head again. I do anything I can to get it out, but it's hard, for example, in June I have to do the tests again, every time I go I start praying, I pray that nothing will come up in those tests. When the time of the tests comes close, I become distressed, that distress with fear (S2); The first few times, I got into such a state, any little thing that was different, I would straightaway think, is this something to do with it? Could it be something? Once I had rectal bleeding, sweat was worried, could it be...? I looked up a GI specialist, and I went to do tests (S4).

In the Heideggerian meditation, the language is an existential ontological part of the being-there, that is, a positive phenomenon, which constitutes the way that the human being understands and interprets the facts in his mundanity of the world. However, as a project, the Dasein never achieved the ontological reference of the speech, settling for repeating and passing on what is said in the talking. In this case, the chatter is an inauthentic mode of the Being-there being-in-the-world-with the other. ${ }^{9}$

One study which focused on women who had survived cancer corroborates these findings, alluding to the presence of cancer in these peoples' lives as a "ghost", hence, even after the end of the treatment, any sign of its presence makes them relive all the suffering of the past. ${ }^{18}$

In the light of the above, we encompass the language of survivor 2, who states that feeling himself to be cured of cancer is also to live with the chatter of the entities around who do not really seek to understand their situation, as the chatter not only dismisses the task of an authentic understanding but also develops an indifferent comprehensibility from which nothing is excluded. ${ }^{9}$ Similar feelings were found in an experience report published in 2010, in which the author, after surviving cancer of the colon, mentions that "[...] there are people who question you in a normal way, while there are others who don't ask you anything and go around saying things without knowing anything. They came and asked me if I had breast cancer, people who mix information, people who don't call me for fear of how I might react". ${ }^{21: 6}$
The existential phenomenology of perception analyzes the body not as a physical organism, but sees it as a totality, a structure with relation to the things which are there, that is, the meaning is something which occurs in the body itself. ${ }^{22}$ Hence, we also observe, in the account of Survivor 4, that the same reports living in an existential paradox, that is, on the one hand, she once more feels life in her body, but at the same time, lives with the expectation of the reappearance of the disease. This thinking leads us to believe that the experience of being a survivor can only be experienced and felt in all its completeness by the person who survives ${ }^{3}$ and who brings hope, as the same is founded upon an important phenomenon in human life, taking on a special relevance in crisis situations. ${ }^{23}$

\section{Forgetting the temporality of existing with cancer}

The human being in his being-thrown-tothe-world can be manifested inauthentically or authentically. The inauthenticity is a way of Being-there being-in-the-world, but is characterized by abandonment of oneself, that is, the being itself abdicates from itself in favor of the world. In this condition, it forgets its possibility of being a being of care.

In the Heideggerian analysis, the human being is a being-in-the-world with possibilities for transcendence, ${ }^{24}$ this because "our existence is characterized by a having to be which must, each time, that is, in each new situation, be taken on". ${ }^{25: 62}$ In the light of this, we surmise, in the discourses, that after transcending his existential anxiety before the probability of the recurrence of the disease in his life and, experiencing the temporality of being cured, the Being-there abandons himself to lack of care about himself, overlooking his facticity of being a being thrown away in the world, living at the mercy of the facts and occurrences.

In the accounts, we revealed that the temporality of being a cancer survivor immerses them in a state of existential decadence, losing themselves in the banalities of daily life. And, in this state, they cease to value certain important cares for the continuation of their health.

In particular, I feel like this: I [...] I forget what I had, actually. Last year, I even did something I shouldn't have, I should have done my check-ups in the beginning of the year, and in the rush I kept leaving it, leaving it and I only went to the doctor in July. There are times when I am like that, so tranquil that I stopped 
valuing things. Every year I have to do a whole battery of tests, and last year I fell behind with them, so I do them from July onward, I go to the doctor who does the chemotherapy and to the mastologist. In the beginning I was worried about seeing what was changed, becoming apprehensive, but nowadays I do it normally, as if it were a test to check blood sugar, to check cholesterol. This might even be bad, I'm not worried anymore, I think it is bad, because maybe I have stopped valuing something which needs to be monitored better, but I'm really calm, I don't see any more problems (S4). [...] I left hospital, thank God, and I didn't return, I am so casual that I don't even do the tests. My daughter says:' Mom, you need to go to the doctor'; I don't like doctors, but I have to be always at the doctor's. We have to go at least once a year to the doctors, to do a checkup, and everything, but do you think I go? No, I don't. Thank God, no, actually no, my daughter, thank God for not suffering and, sometimes, being traumatized, with depression, no no, I even forget, my daughter, forget, to tell you the truth, I forget that I have already done this, I don't even remember (S5).

In his being-in-the-world, the being-there has the liberty of choosing his own path, living life according to his way of being and feeling the world, "which means taking on responsibilities with the present and with the future" ${ }^{24: 27}$ In the light of this, we can understand from the accounts of S4 and S5 that these demonstrate a way of living fixed to the present. And, imprisoned in this temporality, they let themselves be guided by the situation, overlooking themselves and their care. This attitude may demonstrate that to feel cured is to carry with oneself the ghost of the cancer, as if the same were present in their bodies, but in silence, being able to wake up at any moment. We learn, too, that revealing the phenomenon experienced by the survivors allowed us "the understanding of being in its multiple facets, in its experiences and relationships with the routine world". ${ }^{26: 985}$

From the analysis of the survivors' accounts, in this ontological theme, we also surmise that the confirmation of the cancer and its treatment bring with it routine changes which transform an individual, leaving marks which last for the rest of his life. ${ }^{27}$ Thus, the specter of the cancer and its consternation remain in the memories of those with whom it coexisted, and how it is faced is translated in a form unique to each individual.

\section{REFLECTIONS ON THIS STUDY}

In entering the world of the being-there who survived cancer, we sought not only to glimpse the human being, but to understand this being in her temporal existentiality. And, in this experience, this time is the most immediate phenomenal aspect of the temporality. In this situation, he manifests his way of having survived cancer, as, as an onticontological being, the man reveals to his entities around him the happinesses, the sadnesses, and, mainly, the needs which encompass his onticontological priorities.

The existential phenomenological analysis allowed us to understand the interviewees' feelings, it being the case that, for these, surviving cancer is to find oneself in a temporality which hears, sees and knows; which imagines and expects, and becomes happy and distressed in the context of one's existential facticity.

Hence, through this study, we understand that, in their being-cured, the people come to live with the fog of the disease in their daily life and, at these times, the anxiety is present and the fear of the cancer's recurrence throws them into a distressing state, and, in this $i k$-stante of their lives, that people try in every way to forget their vigor of having been, and this attitude causes them not to accept their responsibilities for the present and future.

However, at some points, the anxiety provides new perspective on life, which is reflected in a new way of facing problems and suffering, with only the feeling of gratitude to a superior entity remaining, for everything which remained in the past. In this way, these individuals now live authentically, demonstrating solicitude for their fellow man, and now inauthentically, turning away from their possibilities of remaining cured.

Based in the feelings constructed over time by the survivors, the need is demonstrated to broaden the nursing professionals' focus, given that this profession has a relevant role in maintaining the health and quality of life of the people who survived cancer, through planning actions directed towards educational processes and psychosocial support for these beings, raising their awareness regarding the importance of self-care through undertaking tests and being monitored by a doctor as a means of detecting any abnormality at an early stage and, thus, being able to live their lives in a full and healthy way.

We are driven like this, to the reflection on the care practised, so as to provide care which covers the needs of these Beings-in-the-world. In this context, it is essential to look to not only their physical dimension, but to the totality of their being. In our opinion, the need for the professional 
to use time as a listening tool for improving the quality of the care is evident, as the temporality of being a cancer survivor revives feelings of anxiety, originating from not having a person with whom they can share the anxieties which cause them physical or mental discomfort or a means of doing so, thus restricting their quality of life.

In spite of the scale of the feelings which emerged among the survivors, the study has limitations, which do not allow us to generalize its findings to all the cancer survivors; however, the opportunity is repeated to offer health professionals some aspects which encompass the experience of these beings and which deserve due attention in relation to their care.

\section{REFERENCES}

1. Martins AM, Almeida SSL, Modena CM. O ser-no-mundo com câncer: o dasein de pessoas ostomizadas. Rev Soc Brasil Psicol Hosp. 2011 JanJun; 14(1):74-91.

2. Silva RCV, Cruz EA. Planejamento da assistência de enfermagem ao paciente oncológico. Rev Enferm Anna Nery. 2011 Jan-Mar; 15(1):180-85.

3. Muniz RM, Zago MMF, Schwartz E. As teias da sobrevivência oncológica: com a vida de novo. Texto Contexto Enferm. 2009 Jun-Mar; 18(1):25-32.

4. Ministério da Saúde (BR). A situação do Câncer no Brasil: sobrevida, estadiamento, relações incidência/ mortalidade [página na Internet]. Rio de Janeiro: Instituto Nacional do Câncer; 2006 [acesso 2013 Jun 06]. Disponível em: http:/ /www.inca.gov.br/ situacao/

5. Ferreira NML, Dupas G, Costa DB, Sanchez KOL. Câncer e família: compreendendo os significados simbólicos. Cienc Cuid Saúde. 2010 Abr-Jun; 9(2):269-77.

6. Sales CA, Silva MRB, Borgognoni K, Rorato C, Oliveira W. Cuidados paliativos: a arte de estarcom-o-outro de uma forma autêntica. Rev Enferm UERJ. 2008 Abr-Jun; 16(2):174-9.

7. Sales CA, Violin MR, Santos EM, Salci MA, D'Artibale EF, Decesaro MN. Cuidados paliativos: relato de experiência de sua aplicabilidade em um projeto de extensão. Cienc Cuid Saúde. 2009 OutDez; 8(supl):125-9.

8. Soares PBM, Carneiro JA, Rocha LA, Gonçalves RCR, Martelli DRB, Silveira MF, et al. The quality of life of disease-free Brazilian breast cancer survivors. Rev Esc Enferm USP. 2013 Fev; 47(1):69-75.

9. Heidegger M. Ser e tempo. $16^{\mathrm{a}}$ ed. Rio de Janeiro (RJ): Editora Universitária São Francisco; 2006.

10. Boemer MR. Sobre cuidados paliativos. Rev Esc Enferm USP. 2009 Set; 43(3):500-1.
11. Josgrilberg RS. A fenomenologia como novo paradigma de uma ciência do existir. In: Pokladek DD, organizadora. A fenomenologia do cuidar: prática dos horizontes vividos nas áreas da saúde, educacional e organizacional. São Paulo (SP): Vetor; 2004. p.31-52.

12. Kirchnner R. A fundamental diferença entre o conceito de tempo na ciência histórica e na física: interpretação de um texto heideggeriano. Veritas [online]. 2012 [acesso 2013 Jun 06]; 57(1):128-42. Disponível em: http:/ / revistaseletronicas.pucrs.br/ ojs/index.php/veritas/article/view/11230/7674

13. Ferreira DB, Farago PM, Reis PED, Funghetto SS. Nossa vida após o câncer de mama: percepções e repercussões sob o olhar do casal. Rev Bras Enferm. 2011 Mai-Jun; 64(3):536-44.

14. Asgeirsdottir GH, Sigurbjörnsson E, Traustadottir R, Sigurdardottir V, Gunnarsdottir S, Kelly E.“To cherish each day as it comes": a qualitative study of spirituality among persons receiving palliative care. Support Care Cancer. 2013 May; 21(5):1445-51.

15. Rodrigues Gomes AM. La espiritualidade ante la proximidad de la muerte. Enfermería Globa [online]. 2011 Abr [acesso 2013 Jun 07]; 10(22):1-10. Disponível em: http://revistas.um.es/eglobal/ article/view/122831/115471

16. Guerero GP, Zago MMF, Sawada NO, Pinto MH. Relação entre espiritualidade e câncer: perspectiva do paciente. Rev Bras Enferm. 2011 Jan-Fev; 64(1):53-9.

17. Salci MA, Marcon SS. Após o câncer: uma nova maneira de viver a vida. Rev Rene. 2011 Abr-Jun; 12(2):374-83.

18. Salci MA, Marcon SS. A convivência com o fantasma do câncer. Rev Gaúcha Enferm. 2010 Mar; 31(1):1825.

19. Pinto C, Ribeiro JL. Avaliação da espiritualidade dos sobreviventes de cancro: implicações na qualidade de vida. Rev Port Sau Pub [online]. 2010 Jan-Jun; [acesso 2013 Jun 06]; 28(1):49-56. Disponível em: http:/ / www.scielo.gpeari.mctes.pt/pdf/rpsp/ v28n1/v28n1a06.pdf

20. Bennion AE, Molassiotis A. Qualitative research into the symptom experiences of adult cancer patients after treatments: a systematic review and metasynthesis. Support Care Cancer. 2013 Jan; 21(1):9-25.

21. Pérez VT. Mi victoria ante el cáncer: El relato de una paciente que ha superado el cáncer de colon. Index Enferm [online]. 2010 Jan-Mar [acesso 2013 Jun 07]; 19(1):60-3. Disponível em: http:/ / scielo.isciii.es / scielo.php?pid=S113212962010000100013\&script=sci_arttext

22. Merleau Ponty M. Fenomenologia da percepção. Trad. Carlos Alberto Ribeiro de Moura. $3^{\mathrm{a}}$ ed. São Paulo (SP): Martins Fontes; 2006.

23. Pinto S, Caldeira S, Martins JC. A esperança da pessoa com cancro: estudo em contexto de quimioterapia. Rev Enferm Ref [online]. 2012 [acesso 
2013 Abr 18]; serIII(7). Disponível em: http:// www.scielo.gpeari.mctes.pt/scielo.php?pid=S087402832012000200003\&script=sci_arttext

24. Sebold LF, Carraro TE. Autenticidade do serenfermeiro-professor no ensino do cuidado de enfermagem: uma hermenêutica Heideggeriana. Texto Contexto Enferm. [online]. 2013 [acesso 2013 Mai 20] 22(1). Disponível em: http:// www.scielo.br/scielo.php? pid $=$ S010407072013000100003\&script $=$ sci_arttext\&tlng $=$ pt

25. Silva EB. Heidegger e a destruição do conceito metafísico tradicional de existência. Inquietude. Rev Est Filos [online]. 2012 [acesso 2013 Mai 20] 3(1).
Disponível em: http:/ / www.inquietude.org/index. $\mathrm{php} /$ revista/article/view/112/130

26. Paula CC, Souza ÍEO, Cabral IE, Padoin SMM. Movimento analítico-hermenêutico heideggeriano: possibilidade metodológica para a pesquisa em enfermagem. Acta Paul Enferm. 2012; 25(6):984-9.

27. Pereira CM, Knob Pinto B, Manfrin Muniz R, Habekost Cardoso D, Pasolius Wexel W. Falling ill and surviving breast cancer: the experience of mastectomized women. Rev Pesq Cuid Fundam [online]. 2013 [acesso 2012 Mai 29] 5(2). Disponível em http://www.seer.unirio.br/index.php/ cuidadofundamental/article/view/2003 